\title{
PEMBELAJARAN DENGAN BAHAN AJAR BERBASIS MASALAH UNTUK MENINGKATKAN KEMAMPUAN PEMECAHAN MASALAH PADA MATA KULIAH ANALISIS VEKTOR MAHASISWA SEMESTER IV PRODI PENDIDIKAN MATEMATIKA TAHUN PELAJARAN 2015/2016
}

\author{
T.Tutut Widiastuti. A, M.Pd \\ Program Studi Pendidikan Matematika \\ UIN Sunan Gunung Djati Bandung, Jalan AH. Nasution 105 Cibiru Bandung \\ Email: widiastuti@uinsgd.ac.id
}

\begin{abstract}
The purpose of thi research is to describe the ability of solving problems through the application of learning with a problem based teaching materials on the subject of vector analysis $4^{\text {th }}$ semester students of mathematics education study program in the academic year 2015/2016. This study used a qualitative approach with classroom action research participants. The hallmark of the classroom action research done in the cycles. Each cycles consists of four phases: planning, implementation, observation, and reflection. Based on the results of this research is: (1) that students problem solving abilities views of mastery learning students has increased 23\% , (2) From the average value of problem solving ability of students increased by 4,2 after improvements in cycle II, (3) Based on observation, the learning process has increased by 9,1\% and student activities increased by 6,25\%, (4) The all object of the interview stated that they were pleased with applied learning. From all the research results have shown that this research has met the success criteria set.
\end{abstract}

Keywords : problem based teaching materials, problem solving skill

\begin{tabular}{|l|}
\hline Abstrak \\
Tujuan dalam penelitian ini adalah untuk mendiskripsikan kemampuan pemecahan \\
masalah melalui penerapan pembelajaran dengan bahan ajar berbasis masalah pada \\
mata kuliah analisis vektor mahasiswa semester IV prodi pendidikan matematika \\
tahun pelajaran 2015/2016. Penelitian ini menggunakan pendekatan kualitatif dengan \\
jenis penelitian tindakan kelas partisipan. Ciri dari penelitian tindakan kelas adalah \\
penelitian yang dilakukan dalam siklus. Masing-masing siklus terdiri dari empat \\
tahapan yaitu perencanaan, pelaksanaan, observasi, dan refleksi. Berdasarkan hasil \\
penelitian dapat diketahui bahwa: (1) kemampuan pemecahan masalah mahasiswa \\
dilihat dari ketuntasan belajar mahasiswa mengalami peningkatan sebesar 23\%, (2)
\end{tabular}


dilihat dari nilai rata-rata kemampuan pemecahan masalah mahasiswa meningkat sebesar 4,2 setelah perbaikan pada siklus II, (3) berdasarkan hasil observasi, proses pembelajaran mengalami peningkatan sebesar $9,1 \%$ dan aktivitas mahasiswa mengalami peningkatan sebesar $6,25 \%$, (4) seluruh objek wawancara menyatakan bahwa mereka senang dengan pembelajaran yang diterapkan. Dari seluruh hasil penelitian yang diperoleh telah menunjukkan bahwa penelitian ini telah memenuhi kriteria keberhasilan yang ditetapkan.

Kata Kunci : bahan ajar berbasis masalah, kemampuan pemecahan masalah

\section{PENDAHULUAN}

Dalam kehidupan suatu negara, pendidikan memegang peranan untuk menjamin kelangsungan hidup negara dan bangsa, karena pendidikan merupakan sarana untuk meningkatkan dan mengembangkan sumber daya manusia. Di era globalisasi ini masyarakat Indonesia dengan laju pembangunannya masih menghadapi masalah pendidikan yang amat berat terutama berkaitan dengan kualitas, relevansi, dan efisiensi pendidikan. Upaya peningkatan kualitas mahasiswa pun terus-menerus dilakukan baik secara konvensional maupun inovatif, di antaranya upaya yang dilakukan pemerintah dalam bidang pendidikan adalah dengan adanya perubahan kurikulum yang diberlakukan di Indonesia. Kurikulumkurikulum tersebut disusun sebagai landasan pembelajaran untuk mengembangkan kemampuan berfikir logis, analitis, sistematis, kritis, kreatif, dan bekerja sama serta dimaksudkan pula untuk mengembangkan kemampuan menggunakan matematika dalam pemecahan masalah dan mengkomunikasikan ide atau gagasan dengan menggunakan simbol, tabel, diagram, dan media lain.

Berdasarkan wawancara yang dilakukan peneliti dengan salah satu dosen Pendidikan Matematika UIN Sunan Gunung Djati Bandung, diperoleh informasi bahwa pembelajaran yang sering dilakukan adalah ceramah. Ceramah dilakukan untuk menjelaskan materi yang dipelajari. Kegiatan pembelajaran dengan ceramah mengakibatkan mahasiswa tidak aktif, hanya mendengarkan dan menerima saja apa yang diberikan oleh dosen karena aktifitas hanya terpusat pada dosen. Ceramah seperti ini mengakibatkan mahasiswa mengeluh pada materi yang disampaikan. Idealnya, untuk dapat memahami suatu konsep matematika diperlukan objek yang konkret dengan melakukan eksplorasi, observasi, manipulasi ide secara mental, dan tidak sekedar hafalan. Dengan demikian penyampaian matakuliah perlu dilakukan dengan cara mengajak mahasiswa melakukan sendiri sesuai dengan gaya belajarnya, sehingga ingatannya menjadi lebih abadi dari pada mereka dicekoki dengan pengetahuan. 
Cara belajar $\begin{array}{r}\text { yang } \\ \text { dengan }\end{array}$
mengutamakan belajar
mengalami sendiri dan belajar dengan
mengerjakan (learning by doing) akan
menjadikan mahasiswa memiliki
pengalaman dalam menemukan konsep. Sehingga mahasiswa tidak menerima secara mentah pengetahuan yang diberikan dosen. Mahasiswa diajak mengikuti proses pengetahuan tentang suatu konsep yang dipelajari secara bertahap dan konstruktif sehingga kondisi pembelajaran tidak lagi berada dalam keadaan dipaksakan. Dalam pembelajaran ini, sistem pembelajaran ditekankan pada kegiatan yang melibatkan semua mahasiswa dengan menekankan cara berpikir kreatif, kritis dalam mengemukakan pendapat, ide maupun gagasan sesuai dengan gaya belajar yang dimiliki dan keberagaman kecerdasan mahasiswa yang meliputi kecerdasan verbal, matematik, ruang, kinestik, musikal dan kecakapan intrapsikis.

Untuk itu peneliti mencoba mencarikan solusi dengan memberikan satu alternatif metode pembelajaran yang memudahkan atau membantu mahasiswa dalam mempelajari matematika yaitu pembelajaran berbasis masalah (problem based learning), selanjutnya disingkat PBL. Menurut Nurhadi (2004), PBL adalah suatu pendekatan pembelajaran yang menggunakan masalah dunia nyata sebagai konteks bagi siswa untuk belajar tentang cara berfikir kritis dan kerampilan dalam pemecahan masalah, serta untuk memperoleh pengetahuan dan konsep yang esensial dari materi pelajaran. Berdasarkan uraian di atas, maka peneliti mengambil judul "Penerapan Pembelajaran dengan Bahan Ajar Berbasis Masalah untuk Meningkatkan Kemampuan Pemecahan Masalah Pada Mata Kuliah Analisis Vektor Mahasiswa Semester IV Prodi Pendidikan Matematika Tahun Pelajaran 2015/2016".

\section{KAJIAN TEORI}

Menurut Boud, Felleti dan Fogarty (Wena, 2009), strategi belajar berbasis masalah merupakan suatu pendekatan pembelajaran dengan membuat konfrontasi kepada siswa dengan masalah-masalah praktis, berbentuk ill-stuctured atau openended melalui stimulus dalam belajar.

Savoie dan Hughes (Wena, 2009) menyatakan bahwa strategi belajar berbasis masalah memiliki beberapa karakteristik antara lain sebagai berikut:

1. Belajar dimulai dengan suatu permasalahan

2. Permasalahan yang diberikan harus berhubungan dengan dunia nyata siswa

3. Mengorganisasikan pembelajaran di seputar permasalahan, bukan di seputar disiplin ilmu

4. Memberikan tanggung jawab yang besar dalam membentuk dan menjalankan secara langsung proses balajar mereka sendiri

5. Menggunakan kelompok kecil

6. Menuntut siswa untuk mendemonstrasikan apa yang telah dipelajarinya dalam bentuk produk dan kinerja 
Menurut Fogarty (Wena, 2009), tahap-tahap strategi belajar berbasis masalah adalah sebagai berikut:

1. Menemukan masalah

2. Mendefinisikan masalah

3. Mengumpulkan fakta

4. Menyusun hipotesis (dugaan sementara)

5. Melakukan penyelidikan

6. Menyempurnakan permasalahan yang telah didefinisikan

7. Menyimpulkan alternatif pemecahan secara kolaboratif, dan

8. Melakukan pengujian hasil (solusi) pemecahan masalah

Sanjaya (2006) mengungkapkan beberapa kriteria bahan pelajaran yang digunakan dalam proses pembelajaran berbasis masalah secara umum adalah sebagai berikut:

1. Bahan pelajaran harus mengandung isu-isu yang mengandung konflik (conflict issue) yanng bisa bersumber dari berita, rekaman, video, dan yang lainnya.

2. Bahan yang dipilih adalah bahan yang bersifat familiar dengan siswa, sehingga setiap siswa dapat mengikutinya dengan baik.

3. Bahan yang dipilih merupakan bahan yang berhubungan dengan kepentingan orang banyak (universal), sehingga terasa menfaatnya.

4. Bahan yang dipilih merupakan bahan yang mendukung tujuan atau kompetensi yang harus dimiliki oleh siswa sesuai dengan kurikulum yang berlaku.
5. Bahan yang dipilih sesuai dengan minat siswa sehingga setiap siswa merasa perlu untuk mempelajarinya.

\section{METODE PENELITIAN}

Pendekatan yang akan digunakan dalam penelitian ini adalah pendekatan kualitatif, karena data yang dikumpulkan berupa data kualitatif yang bersifat deskriptif, yaitu mengenai pembelajaran dengan bahan ajar berbasis masalah. Bogdan dan Taylor (dalam Moleong, 2005:4) mendefinisikan metodologi kualitatif sebagai prosedur penelitian yang menghasilkan data deskriptif berupa kata-kata tertulis atau lisan dari orangorang dan perilaku yang dapat diamati. Menurut mereka, pendekatan ini diarahkan pada latar dan individu tersebut secara holistik (utuh).

\section{Jenis penelitian}

Jenis penelitian yang digunakan dalam penelitian ini adalah penelitian tindakan (action research). Dimyati (Ulfiyah, 2006) menyatakan bahwa penelitian tindakan adalah penelitian tentang suatu realitas sosial dan bermaksud melakukan perbaikan tentang realitas sosial. Penelitian ini menggunakan penelitian tindakan kelas karena penelitian ini bertujuan untuk memperbaiki, meningkatkan praktik pembelajaran di kelas secara berkelanjutan dan menyelesaikan persoalan yang dihadapi seorang pengajar pada waktu di kelas. Di sini pengajar dapat mencobakan suatu gagasan perbaikan dalam praktik pembelajaran, dan melihat pengaruh nyata dari upaya perbaikan tersebut. Jenis penelitian tindakan kelasnya 
yaitu penelitian tindakan kelas partisipasi, yakni peneliti terlibat langsung dalam proses penelitian.

\section{Waktu dan Tempat Penelitian}

Tempat dilaksanakan penelitian ini adalah di kelas B semester IV Fakultas Tarbiyah UIN SGD Bandung Tahun Pelajaran 2015/2016.

\section{Subjek Penelitian}

Target/ Subjek Penelitian dalam penelitian ini adalah mahasiswa semester IV kelas B tahun pelajaran 2015/2016 yang berjumlah 22 mahasiswa.

Data, Instrumen, dan Teknik

\section{Pengumpulan Data}

Data yang dikumpulkan dalam penelitian ini ada dua jenis yaitu:

1. Data kuantitatif, yaitu hasil tes yang diperoleh dari dokumen hasil tes setiap akhir siklus dan nilai dari mengerjakan Lembar Kerja/ worksheet.

2. Data kualitatif, yaitu respon, proses pembelajaran, aktivitas mahasiswa yang diperoleh dari hasil observasi dosen dan mahasiswa, catatan lapangan, dan hasil wawancara.

Instrumen yang digunakan dalam penelitian ini adalah sebagai berikut:

1. Soal tes

2. Pedoman wawancara

3. Lembar Observasi

4. Catatan Lapangan

Teknik pengumpulan data dalam penelitian ini, yaitu:

1. Tes
Tes pada penelitian ini digunakan untuk mendapatkan data peningkatan kemampuan pemecahan masalah mahasiswa yang dilakukan setelah pelaksanaan pembelajaran dengan bahan ajar berbasis masalah. Yang lebih spesifiknya, untuk mendapatkan data peningkatan kemampuan pemecahan masalah mahasiswa dengan menggunakan skor hasil tes mahasiswa dalam mengerjakan soal-soal yang diberikan. Skor tersebut meliputi skor hasil tes pengetahuan prasyarat yang diambil dari dokumentasi, hasil diskusi kelompok mahasiswa pada saat kegiatan pembelajaran berlangsung.

2. Observasi

Observasi dilakukan untuk mengumpulkan data keadaan kelas selama kegiatan pembelajaran berlangsung. Kegiatan yang diamati meliputi aktivitas mahasiswa dalam pembelajaran dan peneliti sebagai pengajar. Observasi dilakukan peneliti dibantu dosen matematika dan seorang teman sejawat. Observasi yang dilakukan berdasarkan lembar pengamatan yang disediakan oleh peneliti. Disini hasil observasi dianalisis menggunakan taraf keberhasilan tindakan. Adapun rumus yang digunakan adalah sebagai berikut:

Prosentase skor rata-rata (SR)

$=\frac{\text { jumlahskor yangdiperoleh }}{\text { jumlah skormaksimal }} \times 100 \%$

Dengan kriteria taraf keberhasilan tindakan sebagai berikut. 
Tabel 1

Persentase Taraf Keberhasilan Tindakan Kelas

\begin{tabular}{ccc} 
& \multicolumn{2}{c}{ Tindakan Kelas } \\
\hline No & $\begin{array}{c}\text { \% } \\
\text { Keberhasilan } \\
\text { Tindakan }\end{array}$ & $\begin{array}{c}\text { Taraf } \\
\text { Keberhasilan }\end{array}$ \\
\hline 1 & $90-100 \%$ & Sangat Baik \\
\hline $\mathbf{2}$ & $80-90 \%$ & Baik \\
\hline $\mathbf{3}$ & $70-80 \%$ & Cukup baik \\
\hline $\mathbf{4}$ & $60-70 \%$ & Kurang \\
\hline $\mathbf{5}$ & $0-60 \%$ & $\begin{array}{c}\text { Sangat } \\
\text { Kurang }\end{array}$ \\
\hline
\end{tabular}

3. Wawancara

Teknik wawancara digunakan untuk mendapatkan gambaran yang lebih mendalam tentang perkembangan, pemahaman, kesulitan dan perasaan mahasiswa mengikuti proses pembelajaran. Wawancara yang dilakukan pada 6 siswa, yang diambil dari salah satu kelompok yang telah ditentukan sebagai subyek penelitian. Pembagian kelompok disesuaikan dengan dokumentasi hasil tes pegetahuan, sehingga didapatkan 2 mahasiswa berkemampuan tinggi, 2 mahasiswa berkemampuan sedang dan 2 mahasiswa lainnya yang berkemampuan rendah.

4. Catatan Lapangan

Pencatatan lapangan dilakukan untuk mendokumentasikan secara teratur segala peristiwa yang terjadi selama pembelajaran berlangsung. Dalam catatan lapangan dapat dilihat seluruh gambaran tentang aktivitas belajar mahasiswa karena catatan lapangan berisi catatan khusus mahasiswa (perilaku mahasiswa, tanggapan mahasiswa, keseriusan mahasiswa, keadaan kelas saat pelaksanaan pembelajaran) dan komentar serta saran dari pengamat.

\section{Teknik Analisis Data}

Analisis data dalam penelitian kualitatif dilakukan pada saat pengumpulan data berlangsung dan setelah selesai pengumpulan data dalam periode tertentu. Aktivitas dalam analisis data yaitu: data reduction (reduksi data), data display (penyajian data), dan conclusion drawing atau verification (kesimpulan dan verifikasi).

Sedangkan data kuantitatif yang diperoleh peneliti, akan dianalisis dengan cara sebagai berikut.

1) Hasil Worksheet

Skor yang diperoleh mahasiswa dari masing-masing komponen yang terdapat di Worksheet, kemudian diperoleh nilai akhir sebagai berikut.

Tabel 2

Format penilaian Worksheet

\begin{tabular}{ll}
\hline Komponen & Skor \\
\hline Memahami masalah & 20 \\
\hline $\begin{array}{l}\text { Merencanakan } \\
\text { penyelesaian }\end{array}$ & 30 \\
\hline $\begin{array}{l}\text { Melaksanakan } \\
\text { perhitungan }\end{array}$ & 50 \\
\hline Jumlah & 100 \\
\hline
\end{tabular}

2) Hasil tes akhir pembelajaran

Dalam penelitian ini tes digunakan untuk mengetahui hasil belajar mahasiswa matakuliah analisis vektor. Hasil tes ini akan digabungkan dengan hasil Worksheet mahasiswa sehingga akan didapat hasil akhir.

3) Hasil penggabungan tes akhir siklus dengan Worksheet 
Cara menghitung nilai penggabungan

Nilai penggabungan

$=\frac{\text { nilai Worksheet }+2 \times \text { nilai tes akhir }}{3}$

Dari hasil penggabungan akan dihitung prosentase mahasiswa yang tuntas dalam pembelajaran. Dengan cara menghitung sebagai berikut:

Prosentase ketuntasan belajar $=$ karena dosen masih belum bisa mengkondisikan kelas.

- Hasil wawancara siklus I

$\sum$ mahasiswa mendapat nilaiAatau B - Hasil Worksheet $\sum$ mahasiswa keseluruhan $\times 10 \mathrm{v} \%$

Dari hasil wawancara yang dilakukan oleh peneliti terhadap subyek wawancara dapat diketahui bahwa, mahasiswa tidak bisa menangkap sebagian penjelasan dosen, karena suara dosen kurang lantang dan kondisi kelas yang kurang kondusif.

(b) Analisis data kuantitatif

Diketahui jumlah mahasiswa yang tuntas belajar adalah 17

HASIL PENELITIAN DAN PEMBAHASAN

\section{Hasil Analisis Data Siklus I}

(a) Analisis data kualitatif

- Hasil pengamatan aktivitas mahasiswa Hasil pengamatan aktivitas mahasiswa yang dilakukan oleh pengamat I dan II, menunjukkan bahwa $80,9 \%$ mahasiswa sudah melaksanakan indikator dan deskriptor dengan baik.

- Hasil pengamatan aktivitas dosen Hasil pengamatan aktivitas dosen yang dilakukan oleh pengamat I dan II menunjukkan bahwa $86,35 \%$ dosen sudah melaksanakan indikator dan deskriptor dengan baik.

- Hasil catatan lapangan

Dari hasil catatan lapangan yang dilakukan oleh pengamat I dan II dapat disimpulkan bahwa kegiatan belajar mengajar belum maksimal, hal ini dapat dilihat dari banyaknya mahasiswa yang ramai mahasiswa dari 22 mahasiswa, dan prosentase ketuntasan belajar mahasiswa berdasarkan Worksheet siklus I adalah $77 \%$. Hal ini menunjukkan bahwa prosentase ketuntasan belajar mahasiswa berdasarkan hasil Worksheet sudah mencapai kriteria keberhasilan yang ditetapkan dan bisa dikatakan tuntas.

- Hasil tes akhir siklus I

Diketahui bahwa nilai rata-rata mahasiswa mencapai 72,2. Sedangkan jumlah mahasiswa yang tuntas belajar hanya 16 mahasiswa dari 22 mahasiswa, dan prosentase ketuntasan belajar mahasiswa adalah $73 \%$. Hal ini menunjukkan bahwa prosentase ketuntasan belajar mahasiswa masih belum mencapai Standart yang ditetapkan. Dari analisis ketuntasan tiap indikator, kemampuan mahasiswa masih rendah pada materi vektor dan skalar. Untuk hasil ketuntasan, tes 
akhir siklus I belum bisa dikatakan tuntas.

- Penggabungan hasil tes siklus I dengan Worksheet Diketahui jumlah mahasiswa yang tuntas belajar adalah 15 mahasiswa dari 22 mahasiswa, dan prosentase ketuntasan belajar mahasiswa adalah $68 \%$ mahasiswa mendapat nilai $\geq 65$ (skala $0-100$ ), dengan rata-rata nilai penggabungan adalah 74,8 .

\section{Hasil Analisis Data Siklus II}

\section{(a) Analisis data kualitatif}

- Hasil pengamatan aktivitas mahasiswa

Diketahui bahwa hasil pengamatan aktivitas mahasiswa yang dilakukan oleh pengamat I dan II, menunjukkan bahwa $87,15 \%$ mahasiswa sudah melaksanakan indikator dan deskriptor dengan baik.

- Hasil pengamatan kegiatan pembelajaran

Diketahui bahwa hasil pengamatan kegiatan pembelajaran yang dilakukan oleh pengamat I dan II menunjukkan bahwa, 95,45\% peneliti sudah melaksanakan indikator dan deskriptor dengan baik.

- Hasil catatan lapangan

Dari hasil catatan lapangan yang dilakukan oleh pengamat I dan II dapat disimpulkan bahwa, kegiatan belajar mengajar sudah maksimal, hal ini dapat dilihat dari keseriusan mahasiswa pada saat kegiatan belajar mengajar.

- Hasil wawancara siklus II
Dari hasil wawancara yang dilakukan oleh peneliti terhadap subyek wawancara dapat diketahui bahwa, mahasiswa senang dengan metode yang diterapkan oleh peneliti. Hal ini ditunjukkan dengan seluruh subjek wawancara yang mewakili 22 mahasiswa menyatakan senang dengan pembelajaran yang diterapkan.

\section{(b) Hasil analisis data kuantitatif}

- Hasil LKS siklus II

Diketahui jumlah mahasiswa yang tuntas belajar adalah 20 mahasiswa dari 22 mahasiswa, dan prosentase ketuntasan belajar siswa adalah 90\%. Hal ini menunjukkan hasil penilaian Worksheet pada siklus II sudah bisa dikatakan tuntas.

- Hasil tes akhir siklus II

Diketahui jumlah mahasiswa yang tuntas belajar adalah 18 mahasiswa dari 22 mahasiswa, dan prosentase ketuntasan belajar siswa adalah $82 \%$. Hal ini menunjukkan bahwa kemampuan pemecahan masalah mahasiswa dalam memecahkan soal-soal matematika sudah mengalami peningkatan.

- Penggabungan hasil tes siklus II dengan Worksheet

Hasil penggabungan tes akhir siklus II dengan Worksheet mahasiswa diketahui bahwa jumlah mahasiswa yang tuntas dalam belajar adalah 20 mahasiswa dari 22 mahasiswa, 
dan prosentase ketuntasan belajar mahasiswa mencapai $91 \%$.

\section{SIMPULAN DAN SARAN}

\section{Simpulan}

Berdasarkan hasil penelitian dari serangkaian kegiatan, kemampuan pemecahan masalah mahasiswa mengalami peningkatan rata-rata sebesar 9 setelah diterapkan pembelajaran dengan bahan ajar berbasis masalah pada siklus I, dan rata-rata peningkatan sebesar 5,4 setelah dilakukan perbaikan pada siklus II. Dengan prosentase ketuntasan pada pelaksanaan siklus I sebesar $68 \%$ atau sebanyak 15 dari 22 mahasiswa yang tuntas dalam belajar, meningkat sebesar $23 \%$ dengan ketuntasan belajar mahasiswa pada pelaksanaan siklus II sebesar 91\% atau sebanyak 20 dari 22 mahasiswa yang tuntas dalam belajar.

\section{Saran}

Berdasarkan uraian simpulan, beberapa saran yang dapat dikemukakan adalah:

1. Dapat memanfaatkan hasil penelitian ini sebagai alternatif dalam mengambil kebijakan tentang segala hal yang terkait dengan proses belajar mengajar di Instansi.

2. Dapat melaksanaan pembelajaran tidak sampai siklus II dalam arti dengan siklus I saja mendapatkan hasil yang baik.

3. Dapat mengembangkan penelitian penerapan dengan bahan ajar berbasis masalah, misalnya memadukan dengan metode lain pada matakuliah yang lain pula.

\section{DAFTAR PUSTAKA}

Moleong, L.J. 2005. Metodologi Penelitian Kualitatif Edisi Revisi. Bandung : PT. Remaja Rosda Karya.

Nurhadi, Dkk. 2004. Pembelajaran Kontekstual dan Penerapannya dalam KBK. Malang: Universitas Negeri Malang.

Sanjaya, W. 2006. Psikologi Pendidikan dengan Pendekatan Baru. Bandung : PT. Remaja Rosda Karya.

Ulfiyah, E. 2006. Penerapan Model Pembelajaran Berdasarkan Masalah pada Pokok Bahasan Geometri Kelas I Madrasah Aliyah Ma'arif Sumurber Panceng Gresik Tahun 2004/2005. Skripsi tidak diterbitkan. Malang: UNISMA.

Wena, M. 2009. Strategi Pembelajaran Inovatif Kontemporer. Jakarta: Bumi Aksara. 